\title{
Quadruple Cancers in a Human T-Cell Leukemia Virus Type 1 Carrier
}

\author{
Tatsuyuki Mori, Kazunori NaKase, Kota Tsuj, Syozaburo Nagaya, Takeshi Ikeda, \\ Motoaki Tanigawa, Shigehisa Tamaki, Eiki Miyanishi, Kenkichi KItA* and Shigeru ShIRAKaWA*
}

\begin{abstract}
Human T-cell leukemia virus type 1 (HTLV-1) infection is considered to contribute to the risk of malignancies other than adult T-cell leukemia. We report a 64-year-old male HTLV-1 carrier who developed quadruple malignancies such as cancer of the urinary bladder, skin, larynx and liver.

(Internal Medicine 33: 155-157, 1994)
\end{abstract}

Key words: HTLV-1 carrier, multiple cancers

\section{Introduction}

It is well known that human T-cell leukemia virus type-1 (HTLV-1) is the causative pathogen of adult T-cell leukemia (ATL) (1) and HTLV-1 associated myelopathy (2). HTLV-1 is also thought to alter the host immune function and to contribute to the development of other malignancies $(3,4)$.

In this report, we present an HTLV-1 carrier who developed quadruple carcinomas. To our knowledge, multiple cancers totaling four or more have not been reported previously in an HTLV-1 carrier.

\section{Case Report}

A 64-year-old man was admitted to our hospital because of hoarseness in 1989. He and his parents were born in Osaka Prefecture, Japan and both parents had died of unknown cause. Two of his older sisters had died of colon cancer and renal cancer, respectively. He had been a heavy drinker $[360 \mathrm{ml}$ of Japanese rice wine (sake) a day for 35 years] and smoker (15 cigarettes a day for 40 years). There was a history of bladder cancer (Fig. 1A) in 1982, shaped as a pedunculated papillary tumor, approximately $3 \mathrm{~cm}$ in size, and was treated with partial cystectomy and anti-cancer agents of a total intravenous dose of $30 \mathrm{mg}$ Mitomycin C, with Doxorubicin 1,350 mg and Cytarabin $13.5 \mathrm{~kg}$ given intrabladderly. At this time he received blood transfusions (9 units of preserved whole blood, 3 units of red cell concentrates and 21 units of fresh frozen plasma). In addition, he had a total resection of skin cancer (Fig. 1B) of the left auricle, $1.5 \times 1.0 \mathrm{~cm}$ in size, in 1987 . There was no evidence of recurrence of either carcinoma.

Laboratory data on the present admission in 1989 were as follows; red blood cell $366 \times 10^{4} / \mu 1$, hemoglobin $13.5 \mathrm{~g} / \mathrm{dl}$, hematocrit $39.1 \%$, white blood cell $3,300 / \mu 1$ with normal differentials, platelet $8.4 \times 10^{4} / \mu \mathrm{l}$, total protein $7.1 \mathrm{~g} / \mathrm{dl}$, albumin $3.8 \mathrm{~g} /$ $\mathrm{dl}$, total bilirubin $0.7 \mathrm{mg} / \mathrm{dl}$, cholinesterase $0.55 \Delta \mathrm{PH}$, alkaline phosphatase $64 \mathrm{IU} / \mathrm{l}$, glutamate pyruvate transaminase $59 \mathrm{IU} / 1$ and glutamate oxaloacetate transaminase $46 \mathrm{IU} / 1$. Immunoglobulin G (IgG) was $1,060 \mathrm{mg} / \mathrm{dl}, \operatorname{IgA} 217 \mathrm{mg} / \mathrm{dl}$ and $\operatorname{IgM} 71$ $\mathrm{mg} / \mathrm{dl}$. The surface markers of peripheral blood lymphocytes were as follows; CD3 68.7\%, CD4 32.1\% and CD8 38.5\%. Anti-HTLV-1 antibody was positive $(\times 4,096)$ by particle agglutination test and determined by Western blotting. Antihepatitis $\mathrm{C}$ virus (HCV) antibody was also positive in the serum. Vocal code biopsy revealed squamous cell carcinoma (Fig. 1C) (T2NOM0, TNM classification) and he was treated with irradiation in 1989. Also, an echographic examination of the abdomen disclosed a mass lesion, $2.6 \times 2.6 \mathrm{~cm}$ in size, in the liver. He had a partial hepatectomy and was diagnosed as hepatocellular carcinoma (Fig. 1D) with liver cirrhosis in the same year. Neither peripheral lymph node swelling nor abnormal lymphocytes in the peripheral blood smear has been seen during the clinical course. He is alive now and is followed up as an out-patient.

\section{Analysis of HTLV-1}

A monoclonal integration of HTLV-1 proviral DNA was negative by Southern blot analysis. But, viral integration was positive by polymerase chain reaction (PCR) analysis (Fig. 2) on the DNA extracted from the mononuclear cells of peripheral

From the Department of Internal Medicine, Yamada Red Cross Hospital, Misono and *the Second Department of Internal Medicine, Faculty of Medicine, Mie University, Tsu

Received for publication July 27, 1993; Accepted for publication December 26, 1993

Reprint requests should be addressed to Dr. Kazunori Nakase, the Department of Internal Medicine, Yamada Red Cross Hospital, Misono, Mie 516 

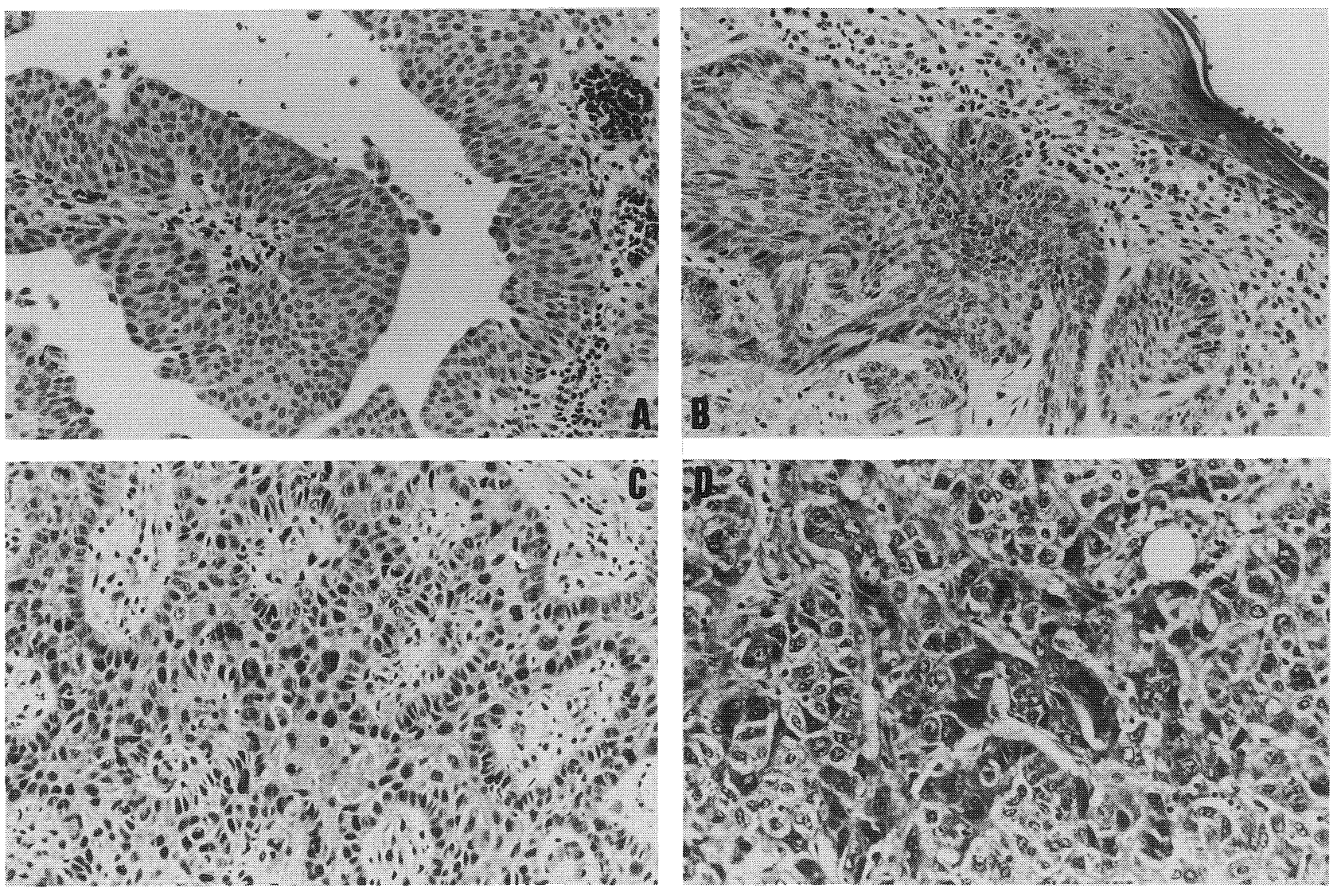

Fig. 1. Histological findings of quadruple carcinomas (HE stain). A) Transitional cell carcinoma of the urinary bladder $(\times 100)$. B) Basal cell carcinoma of the skin $(\times 40)$. C) Squamous cell carcinoma of the larynx $(\times 40)$. D) Hepatocellular carcinoma $(\times 200)$.

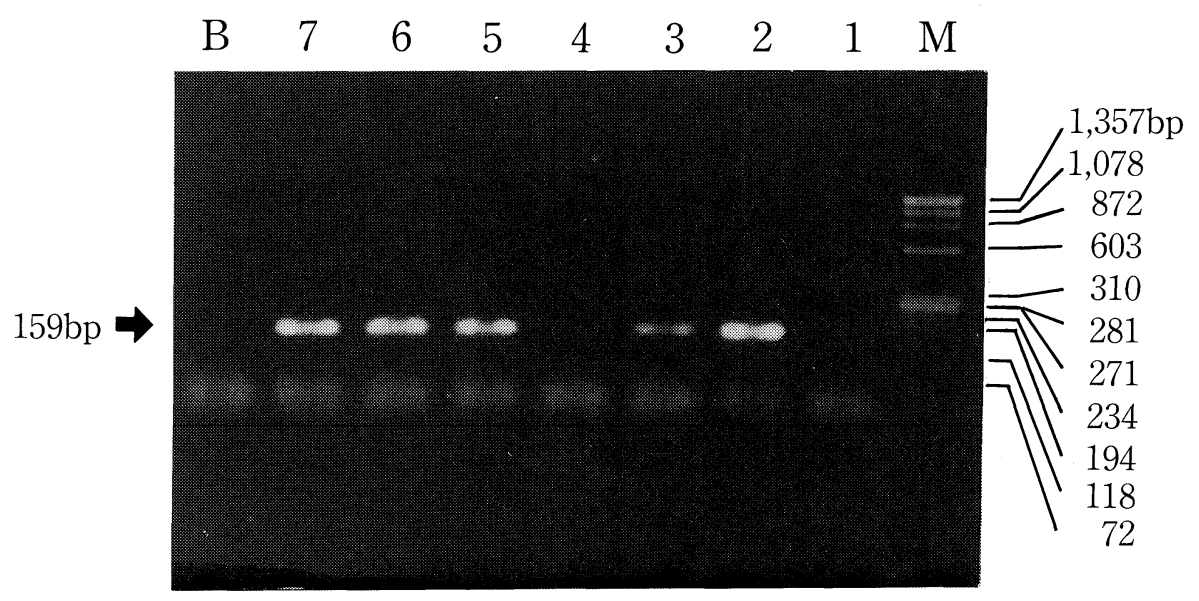

Fig. 2. Analysis of HTLV-1 proviral DNA by PCR method. M, marker (X174-HaeIII fragments). 1) negative control (Raji cell DNA $1 \mu \mathrm{g}$ ). 2) positive control (MT-2 cell DNA $1 \mathrm{ng} /$ Raji cell DNA $1 \mu \mathrm{g}$ ). 3) positive control (MT-2 cell DNA 100 pg/Raji cell DNA $1 \mu \mathrm{g}$ ). 4) positive control (MT-2 cell DNA 10 pg/Raji cell DNA $1 \mu \mathrm{g})$. 5) patient DNA $1 \mu \mathrm{g} .6$ ) patient DNA $500 \mathrm{ng} .7$ ) patient DNA $100 \mathrm{ng} .8$ ) buffer control. 
blood. HTLV-1 proviral DNA on fixed hepatocellular carcinoma cells was not detected by PCR analysis. A probe for proviral DNA used was a $8.25 \mathrm{~kb}$ fragment of $\lambda 23-3$ (Oncor Inc., Gaithersburg, MD). The primer used for PCR was described previously (5).

\section{Discussion}

In this report, we describe a case of HTLV-1 carrier who developed quadruple cancers. The patient was positive for antiHTLV-1 antibody but lacked evidence of overt ATL such as lymph node swelling and abnormal lymphocytes in the peripheral blood smear. So, we diagnosed him as a carrier state of HTLV-1. In this case, two routes of HTLV-1 infection, namely, from mother to child or from donor to recipient in blood transfusion were considered $(6,7)$. ATL has a peculiar geographic distribution in the southwestern part of Japan $(8,9)$. However, since the birthplace of the patient and his mother was not that area, the first route of HTLV-1 infection is unlikely. Concerning the possibility of transmission from wife to husband, we could not test his wife's serum due to her refusal. Though this route can not be completely excluded, it is extremely rare (10). We think that the blood transfusion was the more possible infectious route of HTLV-1 because the patient was transfused before the introduction of a screening system for anti-HTLV-1 antibody in Japan. At that time, he might have also been infected with HCV.

Since the 1970's, many investigators have reported a tendency of multiple primary cancers with increasing incidence $(11,12)$. However, cases with multiple carcinomas totaling four or more are extremely rare (13). A report from Mayo Clinic described only 5 cases $(0.0001 \%)$ of quadruple or more primary cancers in 37,580 consecutive autopsy cases (14). The occurrence of second malignancies due to anti-cancer drugs, especially alkylating agents, has been reported (15). In the present case, Mitomycin C, Doxorubicin and Citarabin were administered for bladder cancer in 1982. To our knowledge, however, the malignancies induced by chemotherapy such as this regimen have not been documented previously. A high HTLV-1 seroprevalence in patients with malignancy irrespective of blood transfusion has been reported (16). Although this issue is controversial (17), HTLV-1 infection was demonstrated to be directly or indirectly associated with the oncogenesis of a malignancy other than ATL $(3,18)$. Matsuzaki et al described monoclonal integration of HTLV-1 proviral DNA in small cell lung cancer cells and suggested its direct involvement in carcinogenesis (19). Our analysis of hepatocellular carcinoma cells did not have this finding. HTLV-1 infection is also thought to alter the host immune surveillance system and to permit evolution of various malignancies (4). The present patient did not show any evidence of immune deficiency as far as we could determine. In this case, however, the development of multiple cancers other than the urinary bladder cancer may have been associated with HTLV-1 infection perhaps by indirect mechanisms though the details are unclear.

\section{References}

1) Yoshida M, Miyoshi I, Hinuma Y. Isolation and characterization of retrovirus from cell lines of human adult T-cell leukemia and its implication in the disease. Proc Natl Acad Sci USA 79: 2031, 1982.

2) Osame M, Usuku K, Izumo S, et al. HTLV-1 associated myelopathy, a new clinical entity. Lancet 1: 1031, 1986.

3) Popovic M, Flomenberg N, Volkman DJ, et al. Alteration of T-cell function by infection with HTLV-1 or HTLV-II. Science 226: 459, 1984.

4) Imamura $\mathrm{N}$, Inada $\mathrm{T}$, Kuramoto $\mathrm{A}$. Multiple primary malignant neoplasms in patients with adult T-cell leukemia. Lancet 1: 219, 1989.

5) Aono $\mathrm{Y}$, Imai J, Tominaga $\mathrm{K}$, et al. Rapid, sensitive, specific, and quantitative detection of human $\mathrm{T}$-cell leukemia virus type 1 sequence in peripheral blood mononuclear cells by an improved polymerase chain reaction method with nested primers. Virus Genes 6:2: 159, 1992.

6) Tajima $\mathrm{K}$, Tominaga $\mathrm{S}$, Suchi $\mathrm{T}$, et al. Epidemiological analysis of the distribution of antibody to adult T-cell leukemia-virus-associated antigen: Possible horizontal transmission of adult T-cell leukemia virus. Gann 73: 893, 1982.

7) Okochi K, Sato H, Hinuma Y. A retrospective study on transmission of adult T-cell leukemia virus by blood transfusion: Seroconversion in recipients. Vox Sang 46: 245, 1984.

8) Takatsuki K, Uchiyama T, Sagawa K, et al. Adult T-cell leukemia in Japan. in: Topics in Hematology, Seno S, Takaku F, Irino S, Eds. Excerpta Medica, Amsterdam, 1977, p. 73.

9) Uchiyama T, Yodoi J, Sagawa K, et al. Adult T-cell leukemia: Clinical and hematologic features of 16 cases. Blood 50: 481, 1977.

10) Hirai K, Takemori N, Onodera R, et al. Possibility of HTLV-1 transmission from wife with ATL to husband. Int J Hematol 55: 305, 1992.

11) Harrison LH, Nordon JM, Resnick MI, et al. Metechronous quadruple malignant neoplasms: A case report and review of the literature. NC Med J 241, 1976.

12) Shintani U, Ohmoto $Y$, Murata $K$, et al. A case of six primary carcinomas. Jpn J Cancer Clin 38: 619, 1992.

13) Watanabe $S$, Kodama $T$, Shimosato $Y$, et al. Multiple primary cancers in 5,456 autopsy cases in the national cancer center of Japan. J Natl Cancer Inst 72: 1021, 1984.

14) Moetel CG. Recent Results in Cancer Research, Vol 17, Springer, New York, 1977, p. 191.

15) Valagussa $P$, Santoro A, Bellani F, et al. Absence of treatment-induced second neoplasms after ABVD in Hodgkin's disease. Blood 59: 488, 1982.

16) Asou N, Kumagai T, Uekihara $S$, et al. HTLV-1 seroprevalence in patients with malignancy. Cancer 58: 903, 1986.

17) Tajima K, Tachibana K. Seroepidemiological study on the prevalence of anti-HTLV-1 antibody in patients with malignancies in an ATL-endemic island, Kyushu-Japan. Proceedings of the Japanese Cancer Association, 47th Annual Meeting, 1988, p. 60 .

18) Imamura $\mathrm{N}$, Inada $\mathrm{T}$, Kuramoto A. Studies on association between the ATL and the development of multiple malignant neoplasms. Jap J Clin Hematol 30: 1744, 1989.

19) Matsuzaki H, Asou N, Kawaguchi Y, et al. Human T-cell leukemia virus type 1 associated with small cell lung cancer. Cancer 66: 1763, 1990. 